\title{
Attacking Character: Ad Hominem Argument and Virtue Epistemology
}

\section{Heather Battaly}

\author{
Philosophy Department, H-214 \\ California State University Fullerton \\ 800 N. State College Blvd. \\ Fullerton, CA 92834-6868 \\ U.S.A. \\ hbattaly@fullerton.edu;
}

\begin{abstract}
The recent literature on ad hominem argument contends that the speaker's character is sometimes relevant to evaluating what she says. This effort to redeem ad hominems requires an analysis of character that explains why and how character is relevant. I argue that virtue epistemology supplies this analysis. Three sorts of ad hominems that attack the speaker's intellectual character are legitimate. They attack a speaker's: (1) possession of reliabilist vices; or (2) possession of responsibilist vices; or (3) failure to perform intellectually virtuous acts. Legitimate ad hominems conclude that we should not believe what a speaker says solely on her say-so.
\end{abstract}

Résumé:

Keywords: ad hominem argument, intellectual vice, intellectual virtue, moral vice, moral virtue, virtue epistemology

Doctor $\mathrm{S}$ has argued that the patient has a bacterial infection, but Doctor $\mathrm{S}$ is cruel. So, we should not believe her diagnosis solely on her say-so.

Doctor $\mathrm{S}$ has argued that the patient has a bacterial infection, but Doctor $\mathrm{S}$ was dogmatic in diagnosing the patient. So, we should not believe her diagnosis solely on her sayso.

(C) Heather Battaly. Informal Logic, Vol. 30, No. 4 (2010), pp. 361-390. 


\section{Introduction}

Direct ad hominem arguments, like those above, attack a speaker's claims or arguments by attacking the speaker's character. ${ }^{1}$ Until recently, such ad hominem arguments were widely repudiated as fallacies of relevance. The speaker's character, it was maintained, is irrelevant to the cogency of her argument: the speaker's argument should instead be judged solely on its own merits, since even cruel and dogmatic people can produce valid and sound arguments. In contrast, much of the recent literature contends that the speaker's character is sometimes relevant to evaluating her claims and arguments, even though it does not affect validity or soundness. Thus, Douglas Walton and Alan Brinton agree that in deliberative contexts, the claims and arguments of speakers who have bad character should be assigned less plausibility. ${ }^{2}$ In a similar vein, Jonathan Adler, Lawrence Hinman and Stephen de Wijze concur that when hearers do not have independent access to the truth-value of a speaker's claims, the speaker's reliability is relevant to whether the hearer should believe those claims. ${ }^{3}$ The sticking point in these recent efforts to redeem direct ad hominem argument has been providing an analysis of character that explains why character is relevant. Here, I argue that virtue epistemology supplies the needed analysis.

Virtue theorists in epistemology define knowledge in terms of intellectual character; and thus, claim that intellectual virtue is necessary for knowledge. Informal logicians and virtue epistemologists agree that we rely on other people for much of our knowledge. As hearers with limited resources and access, we often depend on speakers to transmit knowledge via their claims and arguments. But if this is so, and if virtue theory in epistemology is correct - if the intellectual virtues are required for knowledge - then the speaker's intellectual character is indeed relevant to evaluating her claims and arguments. It is relevant because claims that result from intellectual vices are not likely to be true, and hence are not knowledge. Likewise, arguments that result from intellectual vices are not likely to be valid (if deductive) or strong (if inductive), are not likely to produce true conclusions, and hence are not knowl-

\footnotetext{
${ }^{1}$ Here, I focus on ad hominem arguments that attack a speaker's character. There is a broader sense of 'ad hominem' that includes both attacking a speaker's character and attacking a speaker for logical inconsistencies. This paper addresses only the former-it does not address attacking a speaker for logical inconsistencies.

${ }^{2}$ See Walton 1998, Ch. 5, Ch. 7; Brinton 1985, p. 55; Brinton 1986, p. 249; Brinton 1995, p. 220.

${ }^{3}$ See Adler 2006, p. 239; Hinman 1982, p. 339; de Wijze 2003, p. 41. Also see Woods 2007.
} 
edge-producing. Thus, I will argue that if we discover that Doctor $\mathrm{S}$, in the epigraph above, arrived at her diagnosis dogmatically, then we should not believe her conclusion that 'the patient has a bacterial infection' solely on her say-so. Likewise, if we discover that a speaker has the vice of color-blindness, we should not believe his claim that 'the car leaving the scene was red' solely on his say-so. We should not believe these claims because they issued from intellectual vices (or vicious acts) rather than intellectual virtues, and thus are not likely to be true. Analogously, if we discover that a speaker has the vice of affirming the consequent, or the vice of hasty generalization, or that she is generally deductively or inductively impaired, then we should not believe the conclusions of her arguments solely on her say-so. We should not believe the conclusions of her arguments because her arguments are not likely to be valid or strong and are not likely to produce true conclusions. Of course, a speaker's claims may turn out to be true even if they are not likely to be true, and his arguments may turn out to be valid or strong, even if they are not likely to be valid or strong. But I will contend that if the speaker lacks the intellectual virtues (in specific ways), then he has no knowledge to transmit. Accordingly, if we believe the speaker's claims or the conclusions of his arguments solely on his say-so, then we won't know them either. To put the same point differently: if the speaker is not himself epistemically justified, then he cannot transmit justification to the hearer; at best he can transmit truth. In sum, I argue that virtue epistemology explains why and how character is relevant to evaluating a speaker's claims and arguments. I also contend that intellectual virtues-or components thereof-are necessary for knowledge, and thus that some direct ad hominem arguments are legitimate.

By way of introduction, virtue theories in epistemology define knowledge (a belief-evaluation) in terms of intellectual virtue (an agent-evaluation). Two different analyses of the intellectual virtues have been proposed: virtue-reliabilism and virtue-responsibilism. Reliabilists and responsibilists who define knowledge in terms of the virtues disagree about nearly every aspect of the intellectual virtues. Nevertheless, they agree that the intellectual virtues require reliability. ${ }^{4}$ Virtue-reliabilism and -responsibilism are typically thought to offer incompatible accounts of the intellectual virtues. But here, I assume that the two views are compatible, and that each is partly correct. ${ }^{5}$

\footnotetext{
4 James Montmarquet 1993, and Robert Roberts and Jay Wood 2007, argue that (at least some of) the intellectual virtues do not require reliability. But they also argue that knowledge should not be strictly defined in terms of the intellectual virtues. Here, I restrict my purview to virtue theorists in epistemology who define knowledge in terms of the virtues.

${ }^{5}$ See Battaly 2008.
} 
Led by Ernest Sosa, virtue-reliabilists argue that the intellectual virtues are stable reliable faculties or skills, the paradigms of which include sense perception, induction, deduction, and memory. ${ }^{6}$ They endorse a concept of virtue according to which "anything with a function - natural or artificial-[has] virtues"; and argue that since our primary intellectual function is attaining true beliefs, the intellectual virtues are whatever qualities enable us to do that, be they hard-wired natural faculties or acquired skills (Sosa, 1991, 271). In short, virtue-reliabilists think a quality is an intellectual virtue if it is reliable-if it would produce more true beliefs than false ones. To illustrate, vision (more specifically, color-vision of unoccluded, nearby, medium-sized objects in good lighting) is claimed to be a natural virtue - one that "comes with our brains" (Sosa, 2007, 86). While interpreting CT scans would be an acquired virtue that results from learning. Of course, reliability is not infallibility. Even if a reliable faculty, like vision, produces more true beliefs than false ones, it is not perfect-it will sometimes produce false beliefs. Likewise, an unreliable faculty, like colorblindness, will produce more false beliefs than true ones, but will occasionally produce true beliefs. In sum, according to virtuereliabilists, the intellectual virtues are natural faculties and acquired skills that produce more true beliefs than false ones.

Led by Linda Zagzebski (1996), virtue-responsibilists argue that the intellectual virtues are acquired character traits, the paradigms of which include open-mindedness, intellectual courage, and intellectual autonomy. Responsibilists model their analyses of the intellectual virtues on Aristotle's analysis of the moral virtues. They conceive of virtues as "deep and enduring acquired excellence[s] of a person" that merit praise (Zagzebski, 1996, 137). Accordingly, the virtues are neither natural faculties, nor skills. Rather, like the Aristotelian moral virtues, the intellectual virtues are acquired habits of virtuous action and motivation, for which the agent is partly responsible. But, unlike the Aristotelian moral virtues, their purview is limited to actions and motivations that are involved in belief-formation and transmission. Intellectual actions, virtuous or otherwise, include: e.g., entertaining alternative ideas; searching for evidence; ignoring objections; conceding that another's view is correct; suspending belief; and jumping to a conclusion. Intellectual motivations, virtuous or otherwise, include: e.g., the motivation to believe what is true; the motivation to gain understanding; the motivation to believe whatever will make one feel safe or fit in; and the motivation to believe whatever will get one's name in the trendy journals. Zagzebski argues that each intellectual virtue involves a two-fold motivation: an underlying motivation for truth; which generates a second motivation that is distinctive of the

${ }^{6}$ See Sosa 1991, 2007, 2009. 
intellectual virtue in question $(1996,167)$. To illustrate, the virtue of open-mindedness requires the motivation for truth (which it shares with all of the intellectual virtues), and the motivation to entertain alternative ideas appropriately (which is distinctive of open-mindedness). But to be virtuous, argues Zagzebski, one must also be reliably successful in attaining the ends of these motivations $(1996,177)$. Accordingly, to be open-minded, one must also be reliably successful at entertaining alternatives appropriately, and at getting true beliefs as a result. To be reliably successful at entertaining alternatives appropriately, one must perform intellectual actions that hit the mean between the vices of naïveté and dogmatism: one must entertain alternatives that are highly likely to be true and ignore alternatives that are highly likely to be false. ${ }^{7}$ Moreover, one must produce more true beliefs than false ones as a result of these actions. In short, Zagzebski argues that to be open-minded, one must be (1) motivated to attain true beliefs; and thus (2) motivated to entertain alternatives appropriately; (3) reliably successful at entertaining alternatives appropriately; and thus (4) reliably successful at attaining true beliefs. ${ }^{8}$

Reliabilists and responsibilists who define knowledge in terms of the intellectual virtues agree that whatever else the virtues may be, they are reliable. Here, I assume that virtue-reliabilism and responsibilism each succeed in identifying some of the qualities that make us excellent thinkers. Part of what it is to be an excellent thinker is to be reliable with respect to visual, inductive, and deductive beliefs. Excellent thinkers are also open-minded, intellectually courageous, and intellectually autonomous. So, reliabilism and responsibilism are each partly correct: some of our intellectual virtues are reliabilist faculties and skills, like vision, and others are responsibilist character traits, like open-mindedness.

I will be arguing that a speaker's intellectual character is sometimes relevant to evaluating what he says. What a speaker says includes both claims and arguments. I will contend that the insights of virtue epistemology are applicable to the claims of speakers; specifically to whether those claims are likely to be true or false, and whether they constitute knowledge. I will also contend that they are applicable to the arguments of speakers, specifically whether those arguments are likely to be valid or strong, and whether they are knowledge-producing. Since the connection between virtue epistemology and a speaker's arguments may be less intuitive, I preview it here. Virtue-reliabilists argue that the facul-

\footnotetext{
${ }^{7}$ The naïve person considers too many alternatives; the dogmatic person considers too few. See Battaly 2008. Within the literature on informal logic, see related distinctions in Cohen 2005.

8 Montmarquet (1993) would reject the fourth condition of openmindedness.
} 
ties and skills of induction and deduction are paradigmatic intellectual virtues when they are reliable, and paradigmatic intellectual vices when they are unreliable. We can think of these faculties and skills as sometimes producing conscious arguments that are uttered by the speaker. (Other times, induction and deduction produce beliefs that are uttered by the speaker). Accordingly, if a speaker's faculties and skills of deduction are reliable, he will produce more valid arguments than invalid ones, but will occasionally produce invalid ones. If, on the other hand, his faculties and skills of deduction are unreliable, he will produce more invalid arguments than valid ones, but will occasionally produce valid ones. Presumably, reliable deduction is likely to produce true conclusions; unreliable deduction is likely to produce false conclusions. Consequently, the speaker will know the conclusions of his arguments only if those arguments result from the virtue of reliable deduction. He will not know the conclusion of an argument that results from the vice of unreliable deduction, even if that argument turns out to be valid. Likewise, if a speaker's faculties and skills of induction are reliable, he will produce more strong arguments than weak ones, but will occasionally produce weak ones. Whereas, one whose faculties and skills of induction are unreliable will produce more weak arguments than strong ones, but will occasionally produce strong ones. Presumably, reliable induction is likely to produce true conclusions; unreliable induction is likely to produce false conclusions. Hence, the speaker will know the conclusions of her arguments only if they result from the virtue of reliable induction. She will not know the conclusion of an argument that results from the vice of unreliable induction, even if that argument happens to be strong. ${ }^{9}$

Overall, virtue epistemology and the recent literature on ad hominem argument make for a relatively easy pairing. Section 2 points out that the recent literature on ad hominems already emphasizes the legitimacy of attacking qualities like cognitive skill and honesty ${ }^{10}$ - qualities that virtue epistemologists have elsewhere classified as intellectual virtues. ${ }^{11}$ For instance, Douglas Walton argues that attacks on honesty, judgment, perception, cognitive skills, and personal moral standards are legitimate in deliberative

\footnotetext{
${ }^{9}$ I am grateful to an anonymous referee for emphasizing the distinction between a speaker's claims and arguments.

${ }^{10}$ See Tindale 2007, p. 85; Brinton 1986, p. 250.

${ }^{11}$ Roberts and Wood argue that truthfulness (honesty) is a responsibilist intellectual virtue associated with love of knowledge. See their 2007, p. 164-168, and Ch. 12. Sosa would classify cognitive skills as learned reliabilist-virtues involving induction and deduction. See Sosa 1991, p. 278; and 2007, p. 86.
} 
contexts, though irrelevant in inquiry. ${ }^{12}$ What is missing from the literature on ad hominems is an analysis of the aforementioned qualities (excepting personal moral standards) as intellectual virtues - qualities that (among other things) tend to produce true beliefs. Making explicit use of virtue epistemology, and its analyses of the intellectual virtues, has at least two advantages. It allows us to explain why character is relevant in deliberation and in inquiry, while simultaneously preserving the intuition that ad hominem attacks on the speaker's moral character are often less directly relevant than attacks on her intellectual character.

Section 3 contends that intellectual virtue, or at least one component of it, is indeed required for knowledge. Virtue theory in epistemology is correct. I argue that low-grade knowledge (e.g., that there is a page before you) requires possession of reliabilist virtues (e.g. vision). High-grade knowledge (e.g., that the patient has a bacterial infection) does not require full possession of responsibilist virtues (e.g., open-mindedness), but does require that one perform an intellectually virtuous action (e.g. do what an openminded person would do). Consequently, three sorts of ad hominem arguments that attack the speaker's intellectual character are legitimate. These arguments attack a speaker's: (1) possession of reliabilist vices (e.g., unreliable vision); or (2) possession of fullblown responsibilist vices (e.g., dogmatism); or (3) failure to perform intellectually virtuous acts (e.g., failure to do what an openminded person would do). ${ }^{13}$ The claims of speakers whose vision is unreliable, who are dogmatic, or who fail to appropriately consider alternatives are not likely to be true, and thus are not knowledge. The arguments of speakers whose deduction and induction are unreliable are not likely to be valid or strong, are not likely to produce true beliefs, and thus are not knowledge-producing.

The concluding section identifies two sorts of ad hominem arguments that are illegitimate, including ad hominems that ask us to dismiss the speaker's arguments or conclude that her claims are false. In contrast, legitimate ad hominems merely conclude that we should not believe what the speaker says solely on her say-so. The speaker's arguments should still be evaluated on their logical merits. After all, speakers who have bad intellectual character might still produce sound arguments. Moreover, virtuous hearers might yet gain knowledge from arguments that the speaker produces but whose conclusions she does not herself know. Virtuous hearers might gain knowledge from a speaker, not by believing her conclu-

\footnotetext{
${ }^{12}$ Walton 1998, p. 191, 274.

${ }^{13}$ Ad hominems that attack a speaker's intellectual motives will not be legitimate unless those motives prevent the speaker from performing intellectually virtuous acts.
} 
sions solely on her say-so, but by bringing their own intellectual virtues to bear on the speaker's arguments.

\section{Direct ad hominem argument}

Much of the recent literature on direct ad hominems contends that it is sometimes legitimate to attack a speaker's character, including deficits of moral character, cognitive skill, honesty, and reliability. My virtue epistemological approach contends that it is sometimes legitimate to attack a speaker's intellectual character, including deficits of cognitive skill, honesty, reliability, and openmindedness. These conclusions exhibit considerable overlap, though the arguments for them are different. In this section, I address one of the leading views in the literature on ad hominemsDouglas Walton's - emphasizing significant points of agreement and disagreement with my virtue epistemological approach. Both approaches agree that traits like honesty, and cognitive skills like reliable deduction, are relevant to evaluating what a speaker says. But unlike Walton's view, which restricts the relevancy of these traits and skills to deliberative contexts, the virtue epistemological approach explains why these traits and skills are also relevant in inquiry. It does so by recognizing that we sometimes perform intellectual actions in forming theoretical beliefs. Contra Aristotle and Walton, the contemplative intellect can act; theoretical inquiry can be active. ${ }^{14}$ The virtue epistemological approach enjoys another advantage over Walton's view. By recognizing a class of virtues that is specifically intellectual, and distinct from the moral virtues, it can easily accommodate the intuition that it is often more directly relevant to attack a speaker's intellectual character than her moral character. Attacks on moral and intellectual character need not stand and fall together. Rather, ad hominems that attack a speaker's moral character bear an additional burden: they will not be legitimate unless the Unity of the Virtues Thesis is true.

\section{A Walton: ad hominems are legitimate in deliberation}

Douglas Walton has led the charge to redeem direct ad hominem argument. His Ad Hominem Arguments (1998) contends that direct ad hominems that attack a speaker's honesty, judgment skills, "realistic perception," cognitive skills, or "personal moral standards" are legitimate in deliberative contexts, provided that they do not conclude too much (191). Legitimate ad hominems do not dismiss

${ }^{14}$ At Nicomachean Ethics 1139a35-37, Aristotle argues that "intellect itself...moves nothing, but only the intellect which aims at an end and is practical..." 
the speaker's argument or conclude that it is invalid; they merely lower its plausibility (Walton 1998, 273).

Walton uses Aristotle's Nicomachean Ethics II and VI to argue for the above conclusion. His argument has eight steps. First, Walton supplies his own account of deliberation: a dialogue that has the goal of using reasoning to settle on a course of action that can solve a practical problem. ${ }^{15}$ But he turns to the Nicomachean Eth$i c s$ for an analysis of character, since the literature on ad hominems is silent on such matters. ${ }^{16}$ Accordingly, his second step is to endorse Aristotle's famous definition of moral virtue at NE.II.6, according to which moral virtue is "a state of character concerned with choice, lying in a mean, the mean relative to us, this being determined by a rational principle, and by that principle by which the man of practical wisdom would determine it" (1106b36-1107a2). Third, Walton contends that deliberation (as defined above) requires practical reasoning. Participants in a deliberation share the goal of solving a specific practical problem, and use practical reasoning to generate means to that goal. For instance, in a deliberation about how to treat Patient $\mathrm{P}$, doctors share the goal of curing $\mathrm{P}$, but may endorse different means for doing so-e.g., antibiotics, or surgery. In Aristotelian terms, practical reasoning is what supplies the minor premise in a practical syllogism, for instance:

(Major Premise) I want to cure Patient P.

(Minor Premise) Treating Patient $\mathrm{P}$ with antibiotics is a means to a cure.

So, treating Patient $\mathrm{P}$ with antibiotics is a reasonable course of action.

Fourth, Walton argues that practical wisdom is the ability to excel at practical reasoning: if one excels at practical reasoning, then one

${ }^{15}$ Walton, 1998, p. 183. Walton's notion of deliberation is broader than Aristotle's. Walton thinks that all practical syllogisms are deliberative, whereas Aristotle thinks that only a subset of practical syllogisms are deliberative. For Aristotle, deliberation requires choice, and choice requires rational desire (boulesis): desiring something because it appears good. If the desire in the major premise of a practical syllogism is the result of appetite, rather than boulesis, Aristotle thinks the syllogism is not deliberative. Hence, according to Aristotle, we can engage in meansend reasoning without deliberating.

${ }^{16}$ See Walton, 1998, p. 137: "The scholarly literature on the ad hominem argument and the resources available in the field of argumentation theory give us no direction on how to analyze the concept of a person ['s character]." See also p. 177: "the biggest gap in the literature on ad hominem is that of defining the concept of character in the abusive [direct] subtype." 
has practical wisdom. ${ }^{17}$ Fifth, he maintains that there are several "ingredients" in practical wisdom, including perceptual knowledge, scientific knowledge (episteme), intuitive reason (nous), skill (techne), and judgment. ${ }^{18}$ Sixth, he concludes that since excellent deliberation requires excellent practical reasoning, and excellent practical reasoning involves skills in perception, cognition, and judgment, ad hominems that attack deficits of these skills are legitimate in deliberative contexts. To illustrate, if we discover that Dr. S above tends to "ignore the facts," "commit elementary logical errors," or "make foolish mistakes," then we should assign her conclusion less plausibility than we otherwise would (Walton, 1998, 191). Seventh, following NE.VI.1144b31-32 Walton asserts that practical wisdom requires the moral virtues. ${ }^{19}$ Consequently, he concludes that since excellent deliberation requires excellent practical reasoning, and excellent practical reasoning involves moral virtue, attacking the moral character of the speaker is also legitimate in deliberative contexts. ${ }^{20}$ Hence, discovering that Dr. S is cruel also warrants lowering the plausibility of the doctor's conclusion.

Though premise four is likely to be false ${ }^{21}$, Walton's argument comes close to recognizing the intellectual virtues as a distinct category of character traits from the moral virtues. For starters, the qualities that Walton identifies as "ingredients" of practical wisdom are themselves, on Aristotle's view, "intellectual virtues." Specifically, episteme (scientific knowledge), nous (intuitive reason), and sophia (philosophical wisdom) are contemplative intellectual virtues, the function of which is to attain "invariable" (necessary) truths - e.g., truths about astronomy and mathematics;

${ }^{17}$ Walton, 1998, p. 190. Aristotle disagrees: he thinks that excelling at practical reasoning is sufficient for cleverness, but insufficient for practical wisdom. See NE.1144a25-29.

${ }^{18}$ Walton, 1998, p. 190. Walton borrows Hamblin's analysis. See Hamblin 1987, p. 206.

${ }^{19}$ In NE.VI, Aristotle contends that one cannot be practically wise unless one desires things that are conducive to the good life. Aristotelian moral virtue is what supplies these desires. In Aristotle's words, "[moral] virtue makes us aim at the right mark, and practical wisdom makes us take the right means" (1144a8-9).

${ }^{20}$ Aristotle does not think that excellent practical reasoning entails moral virtue. Vicious people can excel at practical reasoning - villains can be clever. See NE.1144a27.

${ }^{21}$ Steps six and eight depend on four. Four is false because Walton's notion of deliberation, and hence of practical reasoning, is too broad. Many adults excel at means-end reasoning (e.g. venture capitalists), which is a skill, but few of us have the virtue of practical wisdom, which is not a skill. On the distinction between virtues and skills, see Aristotle NE.II.4 and VI.5. 
while techne (skill) and phronesis (practical wisdom) itself are calculative intellectual virtues, the function of which is to attain "variable" (contingent) truths - e.g., truths about how to act and how to make things (NE.1139a6-8). Moreover, Walton acknowledges that ad hominems often attack a speaker's "bad character for veracity," including deficits of honesty, sincerity, and reliability. ${ }^{22}$ Still, his argument ultimately falls short of recognizing the intellectual virtues as a distinct category. This oversight causes him to treat ad hominem attacks on moral character and ad hominem attacks on cognitive skills as equally relevant. On Walton's view, discovering that Dr. S is cruel is no less relevant than discovering that she is inductively impaired.

But, arguably, our intuitions run to the contrary: we think that ad hominem attacks on a speaker's intellectual character are more relevant than attacks on her moral character. Arguably, we think that the speaker's intellectual character is directly relevant to whether we should believe what she says; not because we think good practical reasoning entails practical wisdom (Walton's premise four), but because we think her intellectual character tells us whether her claims are likely to be true and her arguments are likely to be valid or strong. Roughly, we think good intellectual character-honesty, cognitive skills in induction and deduction, open-mindedness - tends to produce valid and strong arguments and true beliefs; bad intellectual character-dishonesty, skill deficits, dogmatism-does not. So, if we discover that the author of the practical syllogism above consistently makes errors in induction, then we learn that her belief that 'treating Patient $\mathrm{P}$ with antibiotics is a means to a cure' (produced by induction) is not likely to be true, and hence not something we should believe solely on her sayso. Arguably, we also think that moral character is less relevant to whether we should believe the speaker. Dr. Gregory House, the protagonist of the television series House, M.D. is a case in point. Dr. House clearly lacks moral virtue. He consistently insults colleagues and patients, repeatedly violates their rights to privacy, and cares only about solving challenging puzzles, not about the people he saves or even about saving them. Despite his obvious moral deficits, Dr. House is an extremely skilled diagnostician-he almost always solves his cases. His skills in induction, deduction, and his indefatigable pursuit of truth yield arguments that are nearly always valid or strong and diagnoses that are nearly always correct. $^{23}$ Dr. House is often cruel, but if he says that 'treating Patient $\mathrm{P}$ with antibiotics is a means to a cure', then we should believe him. In short, moral character and intellectual character may

${ }^{22}$ Walton, 1998 , p. 2, 179. See also Tindale, 2007, p. 86; and Hinman 1982, p. 339.

${ }^{23}$ See Battaly and Coplan 2009a and 2009b. 
come apart, and if they do, it is intellectual character that is relevant to whether we should believe the speaker.

Virtue epistemologists recognize this. They argue that there is a distinct category of virtues that is specifically intellectual. Unlike the moral virtues, the intellectual virtues are primarily concerned with producing and transmitting true beliefs. Accordingly, virtuereliabilists and -responsibilists agree that the intellectual virtues require reliability. ${ }^{24}$ Consequently, speakers who possess intellectual virtues are likely to produce valid or strong arguments and true beliefs; speakers who lack intellectual virtues (in specific ways) are not. Virtue-reliabilists and -responsibilists also acknowledge that it is possible for the intellectual and moral virtues to come apart. Whether they do come apart depends on whether Aristotle's Unity of the Virtues thesis is true. Aristotle's Unity thesis claims that one cannot be morally virtuous without practical wisdom, or practically wise without moral virtue. ${ }^{25}$ In short, practical wisdom entails, and is entailed by, moral virtue. Walton assumes that the Unity thesis is true (premise seven). But, arguably, it is clearly false with respect to cognitive skills and other qualities that virtue-reliabilists have identified as intellectual virtues. After all, one need not be morally virtuous to possess the intellectual virtue of induction: some villains have highly developed inductive skills. Matters are more complicated with respect to the responsibilist intellectual virtues, but even here, one might think that the Unity thesis is false. Again, Dr. House is a case in point. Dr. House is clearly motivated to get true beliefs, consistently seeks out and considers alternative diagnoses, and consequently arrives at diagnoses that are nearly always true. Hence, he is arguably open-minded, even though he lacks moral virtue.

\section{B Walton: ad hominems are not legitimate in inquiry}

Walton argues that although ad hominem attacks can be legitimate in deliberative contexts, they are not legitimate in the context of inquiry or critical discussion, where "personal or biographical matters concerning the...[speaker]... are irrelevant" (1998, 274). Consequently, arguments given in those contexts must be evaluated solely on their logical merits. ${ }^{26}$ On Walton's view, inquiry and critical discussion are types of dialogue that aim at true justified beliefs, rather than at actions that solve practical problems. In criti-

\footnotetext{
${ }^{24}$ Here, I am solely concerned with virtue-reliabilists and -responsibilists who define knowledge in terms of the intellectual virtues.

${ }^{25}$ See NE.VI.12 and VI.13.

${ }^{26}$ In contrast, the arguments given in a deliberation are evaluated both on their logical merits and on the basis of the arguer's character. See Walton, 1998, p. 274.
} 
cal discussion, each party tries to persuade the others that a particular proposition is true and justified by using evidence to support it (Walton, 1998, 185). In inquiry, "the objective is for all parties to examine all the evidence pro and con, on either side of the issue" with the goal of collaboratively arriving at a true justified belief (Walton, 1998, 13).

Walton contends that in a critical discussion, attacking the speaker's character is only relevant at the procedural level and thus irrelevant in evaluating what the speaker says. That is, attacks on character can only tell us that the speaker is not playing by the rules of the critical discussion; they cannot tell us that we should lower the plausibility of her claims. Walton identifies five character traits that speakers must have if they are to follow the rules of a critical discussion: flexible commitment, evidence sensitivity, empathy, open-mindedness, and critical doubt (1998, 182). In short, speakers must: modify or retract their propositions in accordance with the evidence presented; fairly and accurately represent opposing views; weigh opposing views on their merits; and fairly consider objections to their own arguments. Walton thinks that deficits of these character traits demonstrate that the speaker is not playing by the rules of the game - that she is not taking her role in the critical discussion seriously.

The primary difference between the traits Walton identifies above and the responsibilist intellectual virtues, as described by Zagzebski, is that the latter but not the former require attaining a preponderance of true beliefs. According to Zagzebski, but not Walton, one cannot be open-minded unless one is reliably successful at getting true beliefs. But if this is so, then contra Walton, deficits of open-mindedness can tell us that the speaker's claims are not likely to be true. If the speaker is not open-minded and openmindedness is needed for the sort of knowledge that the speaker purports to have, then we should lower the plausibility of her claims. Accordingly, virtue epistemology has the advantage of explaining why character is directly (not just procedurally) relevant in critical discussion.

Walton argues that character is also irrelevant in inquiry. He conceives of inquiry as theoretical rather than practical, taking inquiry in theoretical physics and mathematics to be paradigmatic. In his words, "an ad hominem argument would be outrageously out of place" in "an exchange of arguments in a physics journal on some technical question about the existence of a subatomic particle" $(1998,276)$. Walton contends that the character of the physicists is not relevant to evaluating their claims about subatomic particles because those claims are theoretical. Their claims should instead be judged solely on the strength of the arguments provided. Had these physicists instead been engaged in an argument about constructing a nuclear reactor in a particular neighborhood, their character 
would have been relevant. ${ }^{27}$ As before, Walton argues that attacks on character can only show that the speakers are not playing by the rules of the game. Physicists who intentionally skew their results to get lucrative grants are merely violating the rules of inquiry.

Walton assumes that inquiry is concerned with belief rather than action-i.e., that we do not perform actions or make deliberative choices in forming beliefs about theoretical matters (1998, 203). He likely inherits this idea from Aristotle, who distinguishes between contemplative virtues - which aim at the "invariable" truths of science - and calculative virtues - which aim at the "variable" truths of living well. According to Aristotle, contemplative virtues involve neither action nor deliberation, since "no one deliberates about the invariable" (NE.1139a14-15). Accordingly, one would only make choices and perform actions in forming beliefs about "variable" (i.e., practical) matters. So, theoretical physicists engaged in a debate about the existence of a subatomic particle would neither perform actions nor make choices.

Virtue-responsibilists take this to be an Aristotelian oversight. They argue, contra Aristotle, that we can perform intellectual actions when forming beliefs about theoretical matters. For instance, as Eugene Garver points out, we can make choices and perform acts in constructing arguments; choices and acts which can be praised or blamed. We can choose premises, defend conclusions, explicitly reject some lines of argument, and ignore others altogether (Garver, 2004, 98). So, in forming beliefs about whether a particular subatomic particle exists, we should expect the physicists above to perform multiple intellectual actions: e.g., to entertain various hypotheses, defend their conclusions with reasons, consider or ignore objections, and revise their views in accordance with new evidence. Some of these will be acts that an intellectually virtuous person would perform; others will be acts she would not perform. But if, contra Walton, we can perform acts and make choices in forming theoretical beliefs, then ad hominem attacks on these acts and choices will sometimes be relevant. They will be relevant when a speaker's actions and choices lower her reliability; namely, when she fails to do what an intellectually virtuous person would do. For instance, physicists who intentionally skew their results are not merely violating the rules of inquiry. In failing to perform intellectually virtuous acts, they are also rendering their claims unlikely to be true. Hence, we should not believe their claims solely on their

\footnotetext{
${ }^{27}$ In a similar vein, ad hominem attacks on philosophers engaged in applied ethics would presumably be legitimate; whereas ad hominem attacks on philosophers engaged in abstract matters would presumably be irrelevant (barring attacks on their logical inconsistency). See Walton's remarks on Rousseau (1998, p. 122), Socrates (p. 203), and Bacon (p. 281).
} 
say-so. It is noteworthy that Alan Brinton (1986) foresees something like this line of reasoning. Brinton, like Walton, argues that ad hominem attacks are sometimes legitimate in deliberative contexts. But Brinton also suggests that ad hominem attacks might be legitimate in inquiry, if the character attacked is "more intellectual" (1986, 255).

\section{Intellectual virtue is necessary for knowledge}

If much of our knowledge is acquired from other speakers, and a speaker must have the intellectual virtues in order to have knowledge, then ad hominems that attack a speaker's intellectual character will be legitimate. Specifically, it will be legitimate to attack a speaker's lack of intellectual virtue, since speakers who lack intellectual virtue will have no knowledge to transmit. Their claims will not count as knowledge; nor will their arguments count as knowledge-producing. Here, I argue that the intellectual virtues (or components thereof) are necessary for knowledge. I enumerate five different necessary conditions that virtue theorists might endorse. I argue that two of these succeed: low-grade knowledge requires the possession of reliabilist virtues; high-grade knowledge does not require full possession of the responsibilist virtues, but does require that one perform an intellectually virtuous action.

Let's begin with the distinction between low-grade and highgrade knowledge. ${ }^{28}$ Low-grade knowledge, the paradigm of which is visual knowledge, is acquired passively. Arguably, one can't help but acquire visual knowledge of nearby objects when one's eyes are open, one's brain is functioning properly, and one is in a well-lighted environment. Accordingly, you cannot help but now know that there is a page before you. In contrast, high-grade knowledge is acquired actively, as a result of intentional inquiryopening one's eyes in an appropriate environment is insufficient. The paradigms of high-grade knowledge include scientific knowledge, moral knowledge, and what we might call 'investigative applied' knowledge, for instance knowing that a patient has a bacterial infection, or that the CEO committed the murder. Suppose that an accountant in a Fortune 500 company has been murdered, and that nobody saw the murder being committed. For a police detective to know that the CEO of the company committed the murder, she must conduct an inquiry: she must formulate a hypothesis, search for confirming and disconfirming evidence, consider alternative suspects, and so on. It would be odd if she could acquire knowledge of the murderer's identity without conducting an inquiry - simply by opening her eyes at the crime scene - so odd that

\footnotetext{
${ }^{28}$ See Zagzebski 1996, p. 273-283; Battaly 2008.
} 
we would think her superhuman. It would be equally odd for a doctor to come to know that a patient has a bacterial infection (undetectable by the naked eye) without formulating hypotheses, performing tests, or considering alternative diagnoses.

I distinguish between low- and high-grade knowledge at the outset so as to avoid an unsuccessful thesis about the intellectual virtues and knowledge. The responsibilist virtues (or components thereof) are not necessary for low-grade knowledge. ${ }^{29}$ The responsibilist virtues require intellectual motivations, which are acquired over time, and voluntary intellectual actions. But, as Jason Baehr and John Greco have shown, low-grade knowledge requires neither acquired motivations nor intellectual actions. ${ }^{30}$ If there is a page before you in broad daylight, your eyes are open, and your visual faculties are functioning well, then you can't help but acquire knowledge that there is a page before you-no intellectual action or acquired motivation is needed. Consequently, the candidate theses below claim that the responsibilist virtues are only necessary for high-grade knowledge. Unlike the responsibilist virtues, the reliabilist virtues are viable necessary candidates for low-grade knowledge; hence the final thesis below. If the reliabilist virtues prove to be necessary for low-grade knowledge, they will also be necessary for high-grade knowledge. After all, our detective cannot know that the CEO committed the crime without visual knowledge, and knowledge that results from reliable induction or deduction.

\section{A Responsibilist virtues and high-grade knowledge}

The strongest candidate thesis claims that full possession of the intellectual virtues and the moral virtues is required for high-grade knowledge.

(UVVK): $\mathrm{S}$ has high-grade knowledge that $\mathrm{p}$ only if S's (true) belief that $\mathrm{p}$ results from a responsibilist intellectual virtue; and one possesses such an intellectual virtue if and only if one possesses all of the virtues, moral and intellectual.

(UVVK) claims that high-grade knowledge requires full possession of the responsibilist intellectual virtues, and that the Unity of the Virtues thesis is true. The Unity thesis maintains that if one lacks any single virtue - moral or intellectual - then one lacks them all; and if one possesses any single virtue, then one possesses them all. If (UVVK) is correct, then ad hominem attacks on both intellectual

${ }^{29}$ Zagzebski (1996, p. 277-81) argues that low-grade knowledge does require components of the responsibilist virtues.

${ }^{30}$ See Baehr 2006, p. 494-495; Greco 2002, p. 296. 
and moral character will be legitimate. Accordingly, we should not believe the diagnosis of a doctor who is dogmatic (solely on his say-so); but nor should we believe the diagnosis of a doctor who is cruel, since a doctor who lacks the moral virtue of benevolence will also lack the intellectual virtues.

The Unity thesis has been widely rejected. ${ }^{31}$ Those who reject it argue that it is possible to be (say) open-minded without being benevolent, benevolent without being just, and intellectually courageous without being open-minded. Dr. House, they argue, has the intellectual virtue of open-mindedness, though he clearly lacks the moral virtues. ${ }^{32}$ Those who reject the Unity Thesis will reject (UVVK). But, even if we were to endorse the Unity thesis, (UVVK) would still be too strong because it requires full possession of the responsibilist intellectual virtues. To see why, let's consider (VK), stripped of the Unity Thesis.

(VK): S has high-grade knowledge that p only if S's (true) belief that $\mathrm{p}$ results from a responsibilist intellectual virtue.

(VK) entails that we cannot have knowledge unless we fully possess (at least one of) the responsibilist intellectual virtues. Robert Roberts and Jay Wood come close to endorsing this view. ${ }^{33}$ They argue that Jane Goodall could not have acquired her high-grade knowledge of chimps without possessing responsibilist intellectual virtues like love of knowledge and practical wisdom $(2007,147)$.

If $(\mathrm{VK})$ is true, ad hominem attacks on intellectual character will still be legitimate. But acquiring the responsibilist virtues is no easy task. To fully possess a responsibilist virtue like openmindedness, one must have acquired particular habits of action and motivation. Specifically, one must have acquired the habit of appropriately entertaining alternative ideas - of hitting the mean in one's actions - and the habit of caring about truth (and about entertaining alternative ideas). Arguably, one must also have rid oneself of competing motivations, since people who must overcome competing motivations in order to entertain alternative ideas are enkratic (continent) rather than open-minded. ${ }^{34} \mathrm{Few}$, if any, of us fully

${ }^{31}$ See, for instance, Adams 2006, 171-199.

${ }^{32}$ Battaly and Coplan 2009a and 2009b.

${ }^{33}$ But, Roberts and Wood (2007) do not propose necessary or sufficient conditions for high-grade knowledge. Rather, they argue that high-grade knowledge in the actual world sometimes contingently requires possession of the intellectual virtues.

34 On the distinction between virtue and enkrateia, see Aristotle NE.VI.1-10. Responsibilists standardly require that one fully possess a virtue in order to count as being virtuous. In contrast, see Swanton 2003, who argues that virtue is a threshold concept. One potential problem for 
possess the responsibilist intellectual virtues. Accordingly, (VK) risks widespread skepticism about high-grade knowledge. In sum, (VK) is still too strong, since high-grade knowledge (though effortful) has been attained by many of us-doctors, detectives, scientists, and philosophers alike.

Zagzebski agrees that high-grade knowledge does not require full possession of the responsibilist virtues. In her words, "intellectual virtue...requires some time to develop... and yet it is likely that...agents can have knowledge long before they are fully virtuous" $(1996,276)$. Instead, she contends that high-grade knowledge requires an agent to perform an act of intellectual virtue. An act of intellectual virtue is "an act that arises from the motivational component of [the virtue], is something a person with [the] virtue would...do in the circumstances, is successful in achieving the end of the...motivation, and is such that the agent acquires a true belief...through these features of the act" $(1996,270)$. To illustrate, to perform an act of open-mindedness, one must: (1) possess the motivational component of open-mindedness; (2) do what an openminded person would do, as a result of that motivation; and (3) acquire a true belief, as a result of that action. ${ }^{35}$ Zagzebski argues that the difference between performing an act of intellectual virtue and fully possessing a virtue consists in the absence or presence of the habit of performing virtuous acts. Thus, an agent might perform acts of open-mindedness from time to time, even though she lacks the habit of entertaining alternative ideas, and thus lacks the virtue of open-mindedness. According to Zagzebski, acts of virtue do still require reliability, since the motivations in (1) and actions in (2) reliably produce true beliefs (1996, 311-12). In short, Zagzebski endorses the following necessary condition:

(MAK): $\mathrm{S}$ has high-grade knowledge that $\mathrm{p}$ only if S's (true) belief that $\mathrm{p}$ results from: (1) the motivational component of a responsibilist intellectual virtue; and (2) an action that an agent who has that virtue would perform.

So, to have high-grade knowledge, one's motives must be intellectually virtuous, and one must (at least this once) do the same thing that a virtuous person would do, were she in the same situation.

If (MAK) is true, ad hominem attacks on intellectual motives and actions will be legitimate. But (MAK) is still too strong, and this for two reasons. First, consider the motivational component of

the threshold view is that it cannot distinguish between virtue and enkrateia. I am grateful to an anonymous referee for raising this point.

${ }^{35}$ One can perform an open-minded act without performing an act of open-mindedness. One performs an open-minded act whenever one does what an open-minded person would do. 
open-mindedness, which includes the motivation for truth and the motivation to entertain alternative ideas appropriately. Responsibilists argue that these motivations must be acquired over time. Contra Aristotle, they think that the motivation for truth can be felt too weakly or too strongly. ${ }^{36}$ One can also care too little or too much about entertaining alternative ideas. Hence, one must learn to hit the mean in one's motivations. Full-blown responsibilist virtues are indeed difficult to acquire, but so are their motivational components. Consequently, (MAK) still risks widespread skepticism about high-grade knowledge.

Second, it seems that one can attain high-grade knowledge by performing acts that an intellectually virtuous person would perform, whatever one's motives. Suppose that scientist F lacks intellectually virtuous motives; instead F is motivated by fame, "competitive opportunism," the desire to win awards, or get his name in the trendy journals (Roberts and Wood, 2007, 144). These motivations cause $\mathrm{F}$ to conduct a thorough and careful investigation of a cutting-edge topic in his field, which, in turn, causes $\mathrm{F}$ to acquire multiple true beliefs about that topic. $\mathrm{F}$ is careful in gathering and evaluating evidence, and performs the same acts that an intellectually virtuous person would perform. We would be hard-pressed to claim that F nevertheless fails to acquire knowledge. Arguably, this description fits James Watson and Francis Crick's discovery of the structure of DNA. ${ }^{37}$ Watson and Crick clearly acquired knowledge, even though their motives were not intellectually virtuous - they were motivated by fame and the desire to win the Nobel prize.

Zagzebski offers two different replies to such examples. First, she suggests that F's motivations for fame may not be reliableeven if they lead F to true beliefs in a "limited range of cases," they will ultimately lead him to believe "what others want to hear" (1996, 315). Since reliability is required for an act of intellectual virtue, $\mathrm{F}$ does not perform such an act and, thus, lacks knowledge. But Zagzebski's first reply misses the mark, provided that: $\mathrm{F}$ does what an intellectually virtuous person would do, and doing what an intellectually virtuous person would do is itself reliable. Reliability need not turn on the agent's motives, when his actions (however caused) are sufficient. So, given that the acts of carefully gathering and evaluating evidence are in fact reliable, F meets Zagzebski's reliability requirement.

Alternatively, Zagzebski replies that scientists like $\mathrm{F}$ are indeed motivated to get truths and thus do possess intellectually virtuous motives. Hence, they do perform acts of intellectual virtue, and do acquire knowledge. She grants that such scientists do not

\footnotetext{
${ }^{36}$ See Battaly 2010.

${ }^{37}$ Compare Roberts and Wood 2007, p. 145, 294-96; and compare Walton 1998, 276.
} 
value the truth for its own sake; rather they value truths solely as a means to external rewards $(1996,316)$. This reply is also problematic. For, if $\mathrm{F}$ only values truths for the fame and money that they bring, then $\mathrm{F}$ is no better than the billionaire who donates money to a hospital solely to get his name on the building and a tax write-off. Since the billionaire's motives are not morally virtuous, F's are not intellectually virtuous. The virtuous person's motives must be admirable: some hospital benefactors do care about patients for their own sakes. Rosalind Franklin arguably cared about the structure of DNA for its own sake. ${ }^{38}$ The motives of $\mathrm{F}$ and our billionaire pale in comparison. So, contra Zagzebski, F's motives are not those of the intellectually virtuous person.

This brings us to the weakest, and most plausible, thesis with respect to high-grade knowledge:

(AK): S has high-grade knowledge that p only if S's (true) belief that $p$ results from an action that an intellectually virtuous agent would perform.

(AK) has three points in its favor. First, it keeps the skeptic at bay. Since it is much easier to do what an intellectually virtuous person would do than it is to acquire intellectually virtuous motives, (AK) makes knowledge easier to attain. All one need do is imitate the action of an open-minded person on a specific occasion and acquire a true belief as a result; one need not have the motive for truth or the habit of entertaining alternatives. Analogously, contemporary virtue ethicists, like Rosalind Hursthouse, have argued that one can perform right actions even if one lacks the motives of the morally virtuous agent and does not usually do what the virtuous agent would do. According to Hursthouse, "An action is right iff it is what a virtuous agent would characteristically...do in the circumstances" $(1999,28)$. Second, (AK) requires reliability. It is reasonable to think that the acts that an intellectually virtuous person would perform-e.g., entertaining relevant alternativesreliably yield true beliefs, and that the acts that she would not perform-e.g. ignoring relevant alternatives - do not reliably yield true beliefs. Consequently, when we imitate the virtuous person's actions, we too are likely to get truths; and when we fail to imitate her actions, we are not likely to get truths. To illustrate, though we are not likely to correctly diagnose a patient (whose illness is undetectably by the naked eye) when we fail to run any medical testswhen we fail to do what the intellectually careful person would do-we are likely to get a true belief when we gather and evaluate evidence from relevant tests and journals. Similarly, though we are not likely to correctly identify a murderer (who went unseen) when

${ }^{38}$ See Roberts and Wood 2007, 296-98. 
we fail to consider alternative suspects - when we fail to do what the open-minded person would do-we are likely to get a true belief when we entertain and evaluate alternative theories of the crime. Of course, if we were to discover that we were in a demonworld, in which carefully gathering and evaluating evidence and considering relevant alternatives were in fact unreliable, then such acts would not be required for knowledge. Nor would such acts be intellectually virtuous in that world. The intellectually virtuous acts would be whichever acts were reliable in that world. ${ }^{39}$ Third, the distinction between low-grade and high-grade knowledge demonstrates that we must perform intellectual acts in order to attain high-grade knowledge. Opening one's eyes at the crime scene will not yield knowledge of the murderer. It is reasonable to think that the intellectual acts we must perform are those that the intellectually virtuous person would perform, since these are the acts that reliably produce true beliefs.

Since (AK) is plausible, ad hominem attacks on speaker S's intellectual actions are legitimate. If $\mathrm{S}$ fails to do what an intellectually virtuous person would do, then S's belief is not likely to be true and she does not have high-grade knowledge. Hence, it is legitimate to attack $\mathrm{S}$ for failing to act as an intellectually virtuous person would act. To illustrate, suppose that a patient with a complex set of symptoms is examined by Dr. S and her team. They conduct a routine physical exam, on the basis of which Dr. S concludes that the patient has a bacterial infection. Her team disagrees because there are no visual signs of bacterial infection, tests for bacterial infections have been negative, and the patient does not have a fever. Dr. S wholly ignores this evidence and the arguments of her team. Though Dr. S believes that the patient has a bacterial infection, we should not believe this solely on her say-so. It is legitimate for us to point out that Dr. S did not arrive at her diagnosis as a result of doing what an intellectually virtuous person would do. Because of this failure, Dr. S lacks knowledge. Similarly, suppose that $\mathrm{S}$ refuses "to see any of the all-too-obvious signs that her husband [is] having an affair. [His] schedule [is] erratic; he [is] away from home many evenings and...there [are] unexplained phone hang-ups and other signs that, if [noticed and] investigated, would have suggested that he was involved with another woman. But these signs weren't investigated-not at all" (Ickes 2003, 228). $\mathrm{S}$ fails to notice evidence, fails to investigate, and fails to entertain the possibility that her husband is having an affair. As a result of her (in)actions, $\mathrm{S}$ believes that her husband is faithful. But we should not believe this solely on S's say-so. Again, it is legitimate for us to point out that $\mathrm{S}$ did not do what an intellectually virtuous

${ }^{39}$ Compare Zagzebski 1996, p. 185; Montmarquet 1993, p. 20. 
person would have done. S's failure prevents her from having knowledge.

It is also usually legitimate to attack a speaker for possessing a full-blown responsibilist vice, like dogmatism. For if the speaker possesses a full-blown responsibilist vice, then she habitually fails to do what an intellectually virtuous person would do. She habitually ignores alternatives that the open-minded person would consider. Hence, it is highly likely that she has ignored such an alternative on the occasion in question. Still, it is important to note that on rare occasions, those who possess responsibilist vices will perform virtuous acts, and attain high-grade knowledge. A dogmatist will, rarely, do what an open-minded person would do. This is possible because virtues and vices are dispositions, not guarantees. Consequently, when an intellectually vicious person does perform an intellectually virtuous act, it is not legitimate to attack her claim. Nor is it legitimate to attack a speaker for failing to possess a fullblown intellectual virtue (like open-mindedness) or moral virtue (like benevolence), or for failing to have intellectually virtuous motives. Such a speaker may, with some frequency, do what an intellectually virtuous person would do, even though she lacks the virtues and virtuous motives. For instance, a student may frequently consider alternative ideas in her written papers for a class, even though her motive is not truth, but getting a good grade. ${ }^{40}$ In short, if Dr. $\mathrm{S}$ is fully dogmatic, then it is legitimate to attack her diagnosis, unless we have stumbled on a rare occasion in which she arrived at that diagnosis by doing what an intellectually virtuous person would do. Attacking Dr. S's moral character, her failure to be fully open-minded, or her failure to care about the truth is irrelevant, as long as Dr. S performs an intellectually virtuous act.

\section{B Reliabilist virtues and low-grade knowledge}

Let's turn to low-grade knowledge. Virtue-reliabilists have argued for (RELVK):

(RELVK): $\mathrm{S}$ has low-grade knowledge that $\mathrm{p}$ only if S's (true) belief that $p$ results from a reliabilist intellectual virtue.

\footnotetext{
${ }^{40}$ A student will reliably consider alternative ideas despite caring only about getting a good grade, if her professor is motivated to get truth and grades accordingly. The student herself need not care about truth. Given that some websites now pay students to get good grades, our student might even be ultimately motivated to get money. I am grateful to an anonymous referee for raising this point.
} 
For instance, Ernest Sosa has argued that S has "animal knowledge" that $p$ only if S's belief that $p$ is accurate (true), adroit (manifests an intellectual virtue), and apt (true because it manifests an intellectual virtue). ${ }^{41}$ In short, Sosa thinks that low-grade knowledge requires that one possess reliabilist virtues, like vision and memory, and that one arrive at a true belief because one possesses those virtues (not because of luck). How reliable must a stable faculty be in order to count as a virtue? Following standard practice, we can assume that any stable faculty that would produce more true beliefs than false ones counts as a reliabilist virtue; and any that would produce more false beliefs than true ones counts as a reliabilist vice.

(RELVK) has three points in its favor. First, it does not make low-grade knowledge too difficult to attain. Though responsibilist virtues are difficult to acquire, many reliabilist virtues - vision, memory, induction, deduction, and introspection-develop naturally without any effort on the part of the agent. The reliabilist virtues do not require one to perform intellectual actions or possess acquired intellectual motivations. Accordingly, as long as one's color vision is reliable, one can come to know that (e.g.) the wall is white simply by opening one's eyes in the appropriate environment. Second, relatedly, (RELVK) explains how adults can share low-grade knowledge with children, and perhaps animals. Since children have reliabilist virtues like color-vision, they too have low-grade knowledge that the wall is white. Third, (RELVK) does justice to the intuition that epistemically justified beliefs are likely to be true.

The standard internalist objection to views like (RELVK) argues that there is a demon-world where our counterparts have the same experiences, beliefs, and faculties that we have, but due to the demons, all of their beliefs are false and all of their faculties are unreliable. Nevertheless, the objection argues, there is a sense in which our counterparts' beliefs are epistemically justified, for they are just like us internally - they reason well, they remember well, and they properly take their experiences into account. Hence, justification and knowledge do not require reliability. I take Sosa's reply to this objection to be successful, though I do not here expect to convince internalists that this is so. Sosa contends that relative to their demon-world, our counterparts lack intellectual virtues, but relative to ours, their faculties are virtuous. Our counterparts' beliefs are justified relative to our world, but not relative to their own. According to Sosa, we only consider our counterparts' beliefs to be

\footnotetext{
${ }^{41}$ See Sosa 2007, 22. Relatedly, see Greco 2003. Sosa and Greco endorse 'credit theories' of low-grade knowledge. Lackey (2007) rejects credit theories.
} 
justified because in our world their faculties would be reliable. ${ }^{42}$ Hence, justification still requires reliability-if a belief is justified in a world, it is likely to be true in that world. Of course, if our faculties turn out to be unreliable in our world, then we are not virtuous, we are not justified, and we lack knowledge.

Since (RELVK) is plausible, attacks on a speaker S's unreliable faculties are legitimate. To illustrate, if $\mathrm{S}$ has the vice of colorblindness, we should not believe his claim that 'the car leaving the scene was red' solely on his say-so. Likewise, if S's memory is unreliable, we should not believe her claim that 'the bill was paid last week' solely on her say-so. In each case, S's claim is not likely to be true - and fails to constitute knowledge-because it results from an unreliable vice rather than a reliable virtue.

(RELVK) can also explain why we should not believe the conclusions of S's arguments solely on S's say-so. If S's induction is unreliable (vicious), $\mathrm{S}$ will produce more weak inductive arguments than strong ones. Presumably, unreliable induction will produce more false conclusions than true ones. Hence, S's unreliable induction is not knowledge-producing - $\mathrm{S}$ does not know the conclusions of her inductive arguments. Accordingly, we should not believe S's conclusions solely on her say-so. This is the case even when $\mathrm{S}$ chances on a strong inductive argument. Suppose that $\mathrm{S}$ standardly produces egregiously weak inductive arguments, but chances on a strong inductive argument this time. Since it is highly unlikely for S to produce a strong inductive argument, she doesn't know her conclusion even when she does happen to produce one. Her impaired induction is not knowledge-producing. Since $\mathrm{S}$ doesn't know her conclusion, we should not believe it solely on S's say-so. Likewise if S's deduction is unreliable (vicious), he will produce more invalid arguments than valid ones. Presumably, unreliable deduction will produce more false conclusions than true ones. Hence, S's unreliable deduction is not knowledgeproducing $-\mathrm{S}$ does not know the conclusions of his deductive arguments. Accordingly, we should not believe S's conclusions solely on his say-so. This is the case even when $\mathrm{S}$ chances on a valid deductive argument. Suppose that $\mathrm{S}$ standardly produces invalid arguments, but chances on a valid one this time. Since it is highly unlikely for $\mathrm{S}$ to produce a valid argument, he doesn't know his conclusion even when he does happen to produce one. His impaired deduction is not knowledge-producing. Since S doesn't know his conclusion, we should not believe it solely on S's say-so.

In sum, I have argued that (AK) and (RELVK) are plausible. Hence, three sorts of ad hominem arguments are legitimate. Those that attack a speaker's: (1) possession of reliabilist vices (e.g., unreliable induction); or (2) possession of full-blown responsibilist

${ }^{42}$ See Sosa 2009, p. 38. 
vices (e.g., dogmatism), given the exception above; or (3) failure to perform intellectually virtuous acts (e.g., failure to do what an open-minded person would do). But one might object that (AK) and (RELVK) are not plausible accounts of testimonial knowledge. Accordingly, Jennifer Lackey (2007) argues that in testimonial knowledge, the hearer's getting a true belief has almost nothing to do with his own intellectual virtues, and everything to do with the virtues of the speaker. To borrow her example, suppose that Morris, who has just arrived at the Chicago train station, asks the first adult passer-by he encounters for directions to the Sears Tower. ${ }^{43}$ The passer-by knows Chicago, knows where the Sears Tower is, and gives Morris impeccable directions, which Morris believes. Lackey contends that Morris knows the location of the Sears Tower even though "it is the passer-by's experience with and knowledge of the city," rather than Morris's own faculties, "that explain why Morris ended up with a true belief rather than a false one" (2007, 352). Lackey thinks this marks a distinction between perceptual and testimonial knowledge. In perceptual knowledge, "the knower...can be said to deserve...credit for her true belief since it is her reliable perceptual faculties that carry the explanatory burden of why she acquired it" $(2007,356)$. But in testimonial knowledge, "there isn't a specific testimonial faculty to which we can turn to shoulder the explanatory burden of why the subject holds the true belief in question" (356, her emphasis). In fact, "the faculties of someone other than the knower herself"- the speaker-shoulder this explanatory burden (356). Lackey concludes that views like (RELVK) and (AK) are false, since they claim that knowledge requires the hearer-Morris - to arrive at a true belief as a result of his own virtuous faculties or acts.

If Lackey's objection succeeds, I have failed to explain the very sort of knowledge that motivates my attempt to redeem ad hominems - the knowledge that speakers transmit to hearers. In reply, I submit that Morris's indiscriminate credulity does not yield knowledge. Lackey argues that since Morris "could have just as easily approached a competent-looking compulsive liar or a directionally challenged speaker," he does not deserve credit for the true belief he acquires $(2007,354)$. But, if Morris is indeed blind to cues that indicate a speaker's incompetence or insincerity, then, arguably, he doesn't acquire knowledge either. I suggest that to acquire testimonial knowledge from a speaker, a hearer must either: (1) possess, what Miranda Fricker calls, a "virtuous testimonial sensibility" "44; or (2) at least do what someone with this virtue would do. Fricker's Epistemic Injustice argues that a virtuous testimonial sensibility is an acquired habit of reliable perception of

\footnotetext{
${ }^{43}$ Lackey 2007, p. 352.

${ }^{44}$ Fricker 2007, p. 77.
} 
speaker credibility $(2007,5)$. Though Morris lacks this virtue because he perceives too many speakers as credible, Fricker argues that we typically lack this virtue because we perceive too few speakers as credible. We inherit gender and racial prejudices from our society, which cause us to see some speakers as less competent than they are. Fricker argues that we must actively overcome these prejudices in order to reliably track speaker credibility (2007, 9296). If Fricker is correct, there is indeed a specific testimonial virtue in the hearer that explains why she arrives at true (rather than false) beliefs in testimonial exchanges. In my view, this testimonial virtue in the hearer must include a specific disposition with respect to speaker competence: the disposition to avoid believing what the speaker says solely on her say-so, once one discovers that the speaker possesses reliabilist vices or has failed to perform intellectually virtuous acts. Hence, (AK) and (RELVK) are plausible, even for testimonial knowledge.

\section{Conclusion}

If the arguments above succeed, intellectual character is sometimes relevant to evaluating a speaker's claims and arguments. This does not mean that all ad hominems that attack a speaker's intellectual vices, or her failures to perform virtuous acts, are legitimate. There are two sorts of ad hominems that are clearly illegitimate: (a) those that conclude that the speaker's claim is false or that her argument is invalid; and (b) those that conclude that we should dismiss the speaker's claim or argument. In contrast, legitimate ad hominems merely conclude that we should not believe what the speaker says solely on her say-so.

Ad hominems that conclude that the speaker's claim is false are illegitimate because it is possible for speakers who possess reliabilist vices, or who fail to perform intellectually virtuous acts, to arrive at true beliefs. ${ }^{45}$ Though such speakers are unlikely to arrive at true beliefs, they can land on truths by chance. After all, being unreliable does not entail that one believes only falsehoods; just that one believes more falsehoods than truths. Of course, truths that are arrived at by chance do not constitute knowledge. Likewise, it is possible for speakers who possess reliabilist vices, or who fail to perform intellectually virtuous acts, to produce valid or strong arguments. Even speakers who lack the reliabilist virtues of deduction and induction can accidentally employ valid or strong arguments. As Lawrence Hinman puts an analogous point: "If Hitler

\footnotetext{
${ }^{45}$ Brinton, de Wijze, and Tindale draw the same conclusion, but for different reasons. See Brinton 1995, p. 214; de Wijze 2003, p. 42; Tindale 2007, p. 86-87.
} 
advanced an argument using modus ponens, it would be valid." ${ }^{, 46}$ Accordingly, it is also illegitimate for an ad hominem to conclude that the speaker's argument is invalid or inductively weak. Nor should an ad hominem demand that we dismiss the speaker's claim or argument, since the speaker's claim may be true and her argument may be sound. Indeed, it is possible for the very same sound argument to be produced by two different speakers, one of whom is intellectually virtuous (or does perform virtuous acts), and the other of whom is not (or does not perform virtuous acts). Both arguments have the same logical merits. The difference is that the second speaker has no knowledge to transmit.

Suppose we are solely interested in gaining knowledge from the second speaker above, and not in the logical merits of her argument. Further, suppose we have discovered that she has no knowledge to transmit because she is intellectually vicious or derelict in performing virtuous acts. Is it then legitimate for us to dismiss what she says? Even here it is illegitimate for us to simply dismiss what a speaker says, since there is more than one way for us to gain knowledge from a speaker. As Edward Craig has insightfully argued, hearers can sometimes gain knowledge from claims that a speaker makes but does not herself know. ${ }^{47}$ Craig distinguishes between "informants"-who do have knowledge to transmit-and "sources of information"-who do not (1990, 35). He argues that a hearer can gain knowledge from a source of information by "using [his] utterance as a piece of evidence, not as a piece of information" (1990, 40). Accordingly, I submit that virtuous hearers can sometimes gain knowledge from a speaker, even when the speaker lacks knowledge herself. For instance, suppose that a student, who lacks the virtue of doing complex philosophical deductions, accidentally endorses a sound argument A in a presentation to the class. Though that student fails to know the conclusion of A, hearers might use their own virtues of philosophical deduction, in combination with the speaker's utterance of A, to gain knowledge of A's conclusion. ${ }^{48}$ Alternatively, to adapt an example from Craig ${ }^{49}$, suppose we discover that an eye-witness to a crime regularly mis-identifies the colors red and green. He regularly mistakes red for green, and green for red. Further, suppose that the eye-witness claims that he saw a red car leaving the scene of the crime. The eye-witness has no knowledge to transmit- he falsely believes that a red car left the scene. But the hearer can still come to know that the car leaving the scene was green by using his own

\footnotetext{
${ }^{46}$ Hinman, 1982, p. 339. Also see Adler 2006, p. 225, 244; Walton 1998, p. 271-75.

47 See Craig 1990, chapter V.

${ }^{48}$ Compare Adler 2006, 233-34.

${ }^{49}$ See Craig's Fred example, 1990, p. 37.
} 
virtue of induction, and knowledge about the eye-witness. In short, virtuous hearers might gain knowledge from a speaker, not by believing what the speaker says solely on her say-so, but by bringing their own intellectual virtues to bear on the speaker's claims and arguments.

The recent literature on ad hominem argument contends that the speaker's character is sometimes relevant to evaluating what she says. This effort to redeem ad hominem argument requires an analysis of character that explains why and how character is relevant. I have argued that virtue epistemology supplies the requisite analysis. Three sorts of ad hominems that attack the speaker's intellectual character are legitimate. These arguments attack a speaker's: (1) possession of reliabilist vices; or (2) possession of responsibilist vices; or (3) failure to perform intellectually virtuous acts. Rather than conclude that we should dismiss what a speaker says, or that her claims are false and her arguments invalid or weak, legitimate ad hominems conclude that we should not believe what a speaker says solely on her say-so. ${ }^{50}$

Acknowledgments. I am grateful to Jason Baehr, Amy Coplan, Claudio de Almeida, Gary Jason, Jonathan Knaup, Michael Lynch, Merrill Ring, Clifford Roth, Bruce Russell, and Mas Yamada for their thoughts about earlier drafts.

\section{References}

Aberdein, Andrew. (2010). Virtue in argument. Argumentation 24(2), 165-179.

Adams, Robert. (2006). A Theory of Virtue. Oxford: Clarendon Press.

Adler, Jonathan E. (2006). Confidence in argument. Canadian Journal of Philosophy 36(2), 225-257.

Aristotle. (1984). Nicomachean Ethics. In Jonathan Barnes (Ed.), The Complete Works of Aristotle. Princeton: Princeton University Press.

Aristotle. (1998). Nicomachean Ethics. Translated by David Ross. New York: Oxford University Press.

Baehr, Jason S. (2006). Character in epistemology. Philosophical Studies 128, 479-514.

Battaly, Heather. (2008).Virtue epistemology. Philosophy

Compass: Epistemology 3(4), 639-663.

${ }^{50}$ Two other recent articles, Aberdein 2010 and Johnson 2009, address similar topics. We all bring the intellectual virtues to bear on the debate over ad hominems, but each of us does so via different arguments. 
Battaly, Heather. (2010). Epistemic self-indulgence. Metaphilosophy 41(1-2), 214-234.

Battaly, Heather and Amy Coplan.(2009a). Is Dr. House virtuous? Film and Philosophy 13, 1-18.

Battaly, Heather and Amy Coplan. (2009b). Diagnosing character. In: Henry Jacoby (Ed.), House and Philosophy, pp. 222-238. Hoboken, NJ: John Wiley \& Sons.

Brinton, Alan. (1985). A rhetorical view of the ad hominem. Australasian Journal of Philosophy 63(1), 50-63.

Brinton, Alan. (1986). Ethotic argument. History of Philosophy Quarterly 3(3), 245-258.

Brinton, Alan. (1995). The ad hominem. In Hans V. Hansen and Robert C. Pinto (Eds.), Fallacies: Classical and Contemporary Readings, pp. 213-222. University Park, PA: The Pennsylvania State University Press.

Cohen, Daniel H. (2005). Arguments that backfire. In David Hitchcock (Ed.), The Uses of Argument, pp. 58-65. Hamilton, Ontario: Ontario Society for the Study of Argumentation.

Craig, Edward. (1990). Knowledge and the State of Nature. Oxford: Clarendon Press.

De Wijze, Stephen. (2003). Complexity, relevance and character: Problems with teaching the ad hominem fallacy. Educational Philosophy and Theory 35(1), 31-56.

Fricker, Miranda. (2007). Epistemic Injustice. Oxford: Oxford University Press.

Garver, Eugene. (2004). The ethical criticism of reasoning. In Garver, For the Sake of Argument, p. 87-108. Chicago: The University of Chicago Press.

Greco, John. (2002). Virtues in epistemology. In Paul K. Moser (Ed.), The Oxford Handbook of Epistemology, 287-315. New York: Oxford University Press.

Greco, John. (2003). Knowledge as credit for true belief. In Michael DePaul and Linda Zagzebski (Eds.), Intellectual Virtue, p. 111-134. New York: Oxford University Press.

Hamblin, C. L. (1987). Imperatives. Oxford: Blackwell.

Hinman, Lawrence M. (1982). The case for ad hominem arguments. Australasian Journal of Philosophy 60(4), 338-345.

Hursthouse, Rosalind. (1999). On Virtue Ethics. Oxford: Oxford University Press.

Ickes, William. (2003). Everyday Mind Reading. Amherst, NY: Prometheus Books.

Johnson, Christopher M. (2009). Reconsidering the ad hominem. Philosophy 84, 251-266.

Lackey, Jennifer. (2007). Why we don't deserve credit for everything we know. Synthese 158, 345-361.

Montmarquet, James A. (1993). Epistemic Virtue and Doxastic Responsibility. Lanham, MD: Rowman \& Littlefield. 
390 Heather Battaly

Roberts, Robert C. and W. Jay Wood. (2007). Intellectual Virtues. Oxford: Clarendon Press.

Sosa, Ernest. (1991). Knowledge in Perspective. New York: Cambridge University Press.

Sosa, Ernest. (2007). A Virtue Epistemology. Oxford: Clarendon Press.

Sosa, Ernest. (2009). Reflective Knowledge. Oxford: Clarendon Press.

Swanton, Christine. (2003). Virtue Ethics: A Pluralistic View. Oxford: Oxford University Press.

Tindale, Christopher W. (2007). Fallacies and Argument Appraisal. Cambridge: Cambridge University Press.

Walton, Douglas. (1998). Ad Hominem Arguments. Tuscaloosa, AL: The University of Alabama Press.

Woods, John. (2007). Lightening up on the ad hominem. Informal Logic 27(1), 109-134.

Zagzebski, Linda T. (1996). Virtues of the Mind. Cambridge: Cambridge University Press. 